\title{
Studies on Gonad Histology and Length at First Maturity of the Rainbow Trout Oncorhynchus mykiss Walbaum, 1792 (Salmoniformes: Salmonidae) from Kashmir
}

\author{
A. Wali, T.H. Shah, F.A. Bhat and I. Mohd \\ SKUAST K, Division of Fisheries Resource Management, FOFy, Rangil-19006, India \\ E-mail: oncorhynchusasifa@gmail.com
}

\begin{abstract}
The present study was conducted on gonad histology and length at first maturity of the rainbow trout Oncorhynchus mykiss Walbaum 1792. The length at first maturity recorded was at $28.7 \mathrm{~cm}$. Histological snaps of immature phase revealed the ovigerous lamellae containing oogonial nests. Early maturing phase showed vascularisation and initiation of yolk formation with the ovaries start occupying the space within abdominal cavity. The oocytes show increase in yolk deposition in the form of globules and appearance of zona pellucida membrane with ooplasmic content was the highlight of the advance maturing phase. Considerable percentage of vittellogenic oocytes were observed within the advance maturing phase. The spawning phase revealed developed ovaries that reflected maturation of oocytes justified by increase in their size, volume, weight and entire abdominal cavity was filled with mature ovaries surrounded by thinnest tunica albuginea and zona pellucida. The presence of the late maturing oocytes and post ovulatory follicles was seen in late maturing phase with conspicuous blood vessels. The histology of spent phase revealed ruptured post-ovulatory follicles and showed irregular folds of zona pellucida and postovulatory follicles. During this phase atretic oocytes were also observed that is highlighting the atresia incase of trout fishes.
\end{abstract}

Keywords: Histology, O. mykiss, Trout farms, Kashmir, Coldwater

Histology, the study of the microanatomy of specific tissues, has been successfully employed as a diagnostic tool within medical and veterinary science since the first cellular investigations were carried out in the mid-nineteenth century (Virchow 1858). Since then, considerable developments have taken place in all aspects of cellular biology with the result that today many novel and sophisticated histological techniques, only recently devised for the mammalian histologist are now available to the fish histopathologist. Before any satisfactory histological sections can be produced from biological material, strict attention has to be paid to its preparation. The very rapid rate of autolysis of fish tissues compared to that of homeotherms means that they must be handled rapidly to prevent degenerative changes within the specimen making ultimate diagnosis either unreliable or impossible.

Histological studies are used to predict many biological phenomena such as fish reproduction for invention of new and effective methods to increase the efficiency of broodstock, increasing fish production. Histological studies determine the peak period of spawning \& exploitation of fish, and biological characteristics and life cycle of a species and provide precise information on gonadal development of a species. A histological study is a prime tool for conserving and protecting fisheries in terms of detecting pathogens, pollutants, and catching the correct stage of spawning to provide protection to broodstock. Diverse anthropogenic activities discharge numerous pollutants into the environment, posing a threat to whole biodiversity, including aquatic life (Dhara et al 2021). Two important sectors of fisheries contribute to the food security and nutrition safety of the growing population, namely inland and offshore fisheries (Mishra et al 2021). In order to avoid overexploitation of fishes, it is extremely important to harvest fish at the right age. This can be tracked using various measures like the Lm, or length at first maturity, which basically provides us with information regarding the length at which the fish is ripe. Providing safety to mature stock of fishes is important to avoid the catching and harvesting of spawners hence providing the fish a chance to reproduce at least once in life time.

\section{MATERIAL AND METHODS}

The study was based on 90 samples of $O$. mykiss, in the length range of 220 to $350 \mathrm{~mm}$ and weight of 85 to $505.5 \mathrm{gm}$, collected from three state owned trout fish farms, namely, Achabal Trout Fish Farm, District Anantnag $\left(33.73^{\circ} \mathrm{N}\right.$ latitutde and $75.24^{\circ} \mathrm{E}$ longitutude); Dachigam Trout Fish Farm, District Srinagar $\left(34.8^{\circ} \mathrm{N}\right.$ latitutde and $74.79^{\circ} \mathrm{E}$ longitutde) and Mammar Trout Fish Farm, District Ganderbal 
$\left(34.21^{\circ} \mathrm{N}\right.$ latitutde and $74.77^{\circ} \mathrm{E}$ longitutde. The samples were collected at random every month between August 2015 to January 2016 from the three sites and length at first maturity and gonadal development was observed during the study.

Length at $1^{\text {st }}$ maturity: The length, at which about $50 \%$ of the fish were mature, was taken as the Length at first maturity $\left(L_{m}\right)$.) The length at first maturity was determined in the spawning season. When their maturity was in stages one and two, they were considered as immature, and those which were in stages three to eight, were considered as mature (Farmer et al 2005). The relation between length and maturity in length classes was demonstrated by plotting (cumulative frequency) of such mature fish in each length group against respective length group ( $10 \mathrm{~mm}$ class intervals).

Gonadal development: Maturity stages were recognized as the basis of color and size of ovary as well as the space it occupied in the abdominal cavity. The diameter of the ova was also taken into consideration which recognizing the different maturity stages. The different developmental stages for the female fish were determined by using the International Council for Exploration of Seas (ICES) scale given by Wood (1930). For histological studies, the preserved ovaries were cut into 1-2 mm size and washed overnight under gentle flow of tap water. The washed tissues were dehydrated with series of concentration of ethyl alcohol $(30,50,70$ and $100 \%)$ and cleared in Xylene A.R. (Himedia). These tissues were embedded into paraffin, following impregnation techniques and sections of $5 \mu$ thickness made by using microtome, and stained with Haematoxylin and Eosin 2\%. Microphotographs of the prepared slides were taken using Olympus (CX31). These photographs were utilized for further study and analysis.

\section{RESULTS AND DISCUSSION}

Length at first maturity: The length at first maturity $\left(L_{m}\right)$ was recorded at $28.7 \mathrm{~cm}$ Alp et al (2003) recorded the length at first maturity in male and female brown trout as $17.4 \mathrm{~cm}$ and $17.8 \mathrm{~cm}$ Arsalan and Aras (2007) also recorded length as

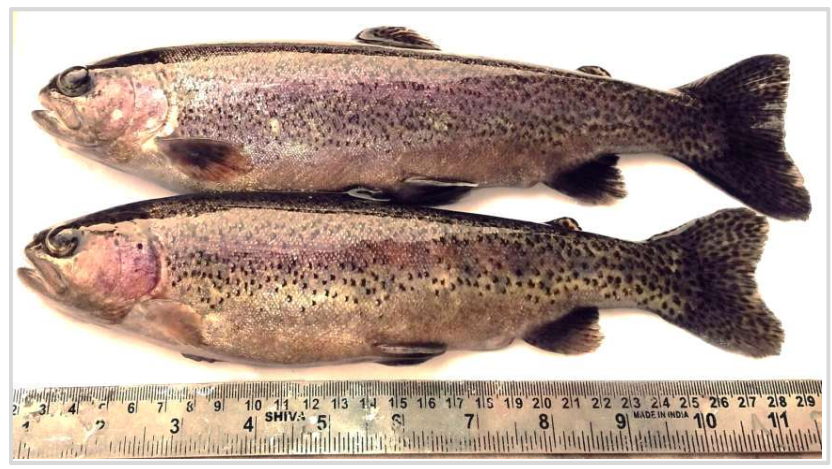

Fig. 1. Specimen of O. mykiss (Walbuam 1792)
14.0 and $17.3 \mathrm{~cm}$ in male and female brown trout. The length at maturity was suggested as the minimum size that should be allowed to be caught in commercial fishing, as it will allow the fish to gain considerable biomass and spawn at least once in its life (Mahmoud, 2009). The onset of maturity differs considerably interspecifically as well as intra-specifically. Information on the size of maturation is essential for avoiding over exploitation of immature juveniles and ensuring the spawning of individual fish at least once in life (Thakran 2014). Hussain (2014) also reported mean length at first maturity $\left(L_{m}\right)$ in males to be $178.14 \mathrm{~mm}$ and in females to be $167.32 \mathrm{~mm}$ in $S$. niger. The differences in $L_{m}$ values in same or different specimens of fishes are mainly due to environmental condition and sampling procedures (Shah 2012). Shah et al (2009) also reported that male rainbow trout attained full maturity after 2 years while female rainbow trouts attained maturity after 3 years in Kashmir.

Gonadal development: The ovarian cycle of O.mykiss showed considerable changes of growth, maturation and degeneration during the different stages. The ovary was enveloped by a thin peritoneal membrane, ovary wall being thin at early stage but with the advancement in maturity it became thick. The three layers that cover ovary are thin squamous epithelium, a thicker tunica albuginea and innermost. The connective tissue, muscle fibres and blood capillaries forms tunica albuginea and with the development of stages during maturation it becomes thinner. The finger like projection or folds formed in germinal vesicles called as ovigerous lamellae contained clusters of germ cells are formed in it. The oogonium arose from the germinal vesicle. On the basis of gross histological examination and changes occurring in ovary and gonadosomatic index, the ovarian cycle of O. mykiss was divided into following six stages:

Stage I: Immature phase: This phase extends from August to September and gonads appear thin thread like structures, translucent or slightly whitish in colour, occupying a very small portion of the abdominal cavity with inconspicuous vascularisation. Examination shows ovigerous lamellae containing oogonial nests (OoN) and immature oocytes. Major portion of oocycte was occupied by the nucleus (ON).

Stage II: Early maturing phase: This phase extends from September to October with increase in size and volume of ovaries, opaque with yellow texture occupying about onehalf of the abdominal cavity. Vascularisation increases, oocytes are visible to the naked eye and beginning of yolk formation in oocytes with scattered yolk droplets (YD) is shown. Peripheral yolk vesicles are observed in oocytes along with a number of late maturing oocytes ( $\mathrm{LmO})$. The ovaries contain both maturing and developing immature oocytes (ImO). Maturing oocytes (MO) were recognized by 
their oval shape and medium size.

Stage III: Advanced maturing phase: This phase extends from October to November shows considerable increase in size, volume and weight of the ovaries which occupy more than three-fourth of the abdominal cavity as oocytes are large, slightly orange in colour due to distinct blood capillaries. Histologically, the oocytes show increase in yolk deposition in the form of globules (YG) and are covered by a zona pellucida/vitelline membrane (ZP/VM) with ooplasmic content $(\mathrm{OC})$ as well. A considerable percentage of vittellogenic oocytes (VO) are observed.

Stage IV: Mature/spawning phase: This phase extends from the month of November to December with fully mature ovaries occupying almost the entire abdominal cavity of the fish and showed further increase in size, volume and weight with increase in oocyte diameter also. The ovaries are fully opaque with orange or yellow tinge and oocytes show full yolk globule (YG) deposition which are also visible to the naked eye. During the phase the fish is ready to expel eggs, if slight pressure is applied to the abdominal area of the fish. The Tunica albuginea becomes very thin as well as zona pellucid (ZP).

Stage V: Late maturingphase: This phase extends from December to January with further increase in size, volume and weight of ovary, fish displays a conspicuously swollen abdomen. Colour of the ovaries acquires a reddish tinge due to increase blood supply of blood. The phase shows late growth of late maturing oocytes ( $\mathrm{LmO}$ ) and post ovulatory follicles. The oocytes attain their maximum size and are covered by zona pellucida (ZP) and zona radiate.

Stage VI: Spent phase: The phase starts from the month of January to February. This phase shows ruptured post- ovulatory follicles (POF) because of which ovaries become shrunken, flaccid, transparent and reduced in size, volume and weight with pale colour. The ovaries show irregular folds of zona pellucida (ZP/VM) and post-ovulatory follicles. Some unexpelled oocytes (UO) can also be observed in the ovaries. During this phase atretic oocytes $(\mathrm{AO})$ were also observed with ooplasmic content (OC).During the present study, the immature ovaries were obtained in August and September and mature ovaries were obtained in November and December while the spent ovaries were found in January, indicating a single reproductive cycle in a year. The ovaries during the spawning phase are filled with yolk laden oocytes (type-IV oocytes) which became so large that interfollicular space was obliterated and septa were stretched to their fullest capacity. Very few immature oocytes were also visible along the peripheral region of the ovary. Towards end of this phase the ovary decreased in weight not only due to ovulation or discharge of the eggs, but also due to degeneration of oocytes which is referred to as atresia (Gadekar 2014), while late maturing phase showed few postovulatory follicles and maturing oocytes covered by zona pellucida/vetilline memberane. During spent phase, degeneration of oocytes has been seen with irregular folds of zona pellucida and post-ovulatory follicles, gonad size reduces and gonads become flaccid leading to atresia. During spent phase degeneration of oocytes has been seen with irregular folds of zona pellucida and post ovulatory follicles and gonad size reduces and become flaccid leading to atresia.The histological examination of ovaries of $O$. mykiss at three sites during the study provides information about the maturity of fish. During the study six different

Table 1. Length-wise percentage distribution of maturity stages in O. mykiss (Female)

\begin{tabular}{|c|c|c|c|c|c|c|c|}
\hline \multirow[t]{2}{*}{ Length group $(\mathrm{mm})$ II } & \multirow{2}{*}{$\begin{array}{l}\text { No. of females } \\
\text { examined }\end{array}$} & \multicolumn{6}{|c|}{ Maturity stages } \\
\hline & & I & II & III & IV & v & VI \\
\hline $220-230$ & 2 & & 100 & & & & \\
\hline $231-240$ & 1 & & & 100 & & & \\
\hline $241-250$ & 1 & 100 & & & & & \\
\hline $251-260$ & 1 & & & 100 & & & \\
\hline $261-270$ & 6 & & & 33.34 & 50 & 16.66 & \\
\hline $271-280$ & 15 & & 6.68 & 33.33 & 33.33 & 13.33 & 13.33 \\
\hline $281-290$ & 10 & & & 40 & 40 & 10 & 0 \\
\hline $291-300$ & 15 & & & 26.66 & 40 & 20 & 13.34 \\
\hline $301-310$ & 9 & & & 22.22 & 33.34 & 22.22 & 22.22 \\
\hline $311-320$ & 6 & & & & 50 & 16.66 & 33.34 \\
\hline $321-330$ & 7 & & & 14.29 & 57.14 & 28.57 & \\
\hline $331-340$ & 1 & & & & 100 & & \\
\hline $341-350$ & 1 & & & & & 100 & \\
\hline
\end{tabular}


stages, immature, early maturing, advance mature, mature, late mature and spent stage were found in O. mykiss at three sites. Sharma and Bhat (2015) reported four distinct reproductive phases viz. resting or spent stage, maturation stage, mature stage and regression stage in O. mykiss of Kashmir.Five developmental stages for golden mahseer have been reported in Bhimtal and Sattal lakes by Shahi et al(2014), five stages of oocytes in Indian major carp Labeo rohita by Gadekar (2014), seven stages in females in Labeo dyocheilus byVerma (2013), six stages of gonad maturation inAuchenoglanis occidentalis by Shinkafi and Ipinjolu (2012), six stages inXenentodon cancila byScuba and Mehta (2012), six main stages in female fishes in Barbus luteus and Varicorhinuus trutta by Rahemo and Al-Shatter (2012). Qadri et al (2019) studied in river Jhelum Kashmir and described maturity phases of reproductive development with about five maturity stages namely Immature phase, Preparatory phase, Maturing phase, Ripe/spawning phase and Spent phase Schizothorax curvifrons.

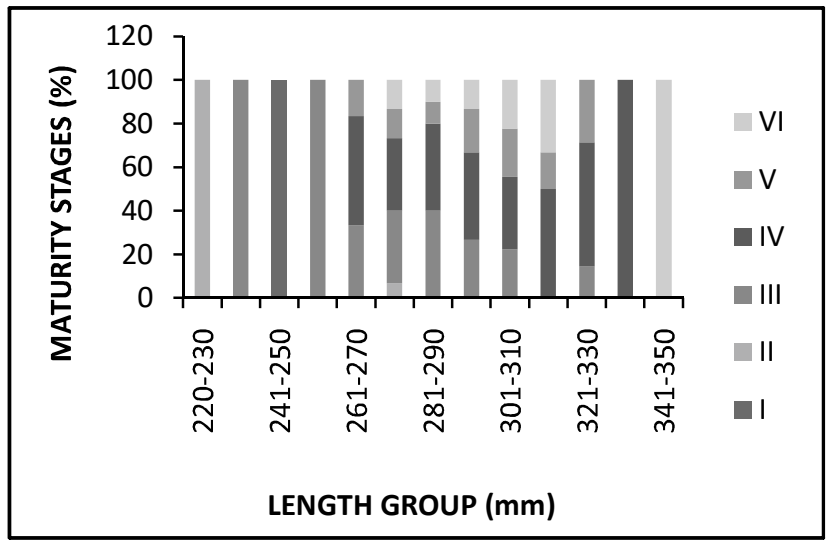

Fig. 2. Percentage distribution of maturity stages in different length groups of $O$. mykiss (Female)

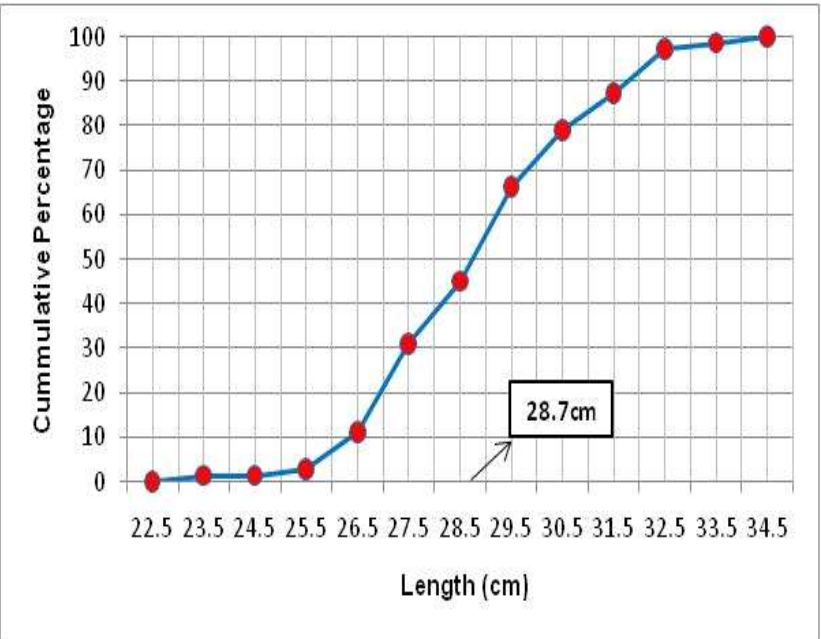

Fig. 3. Length at first maturity in O. mykiss (Female)
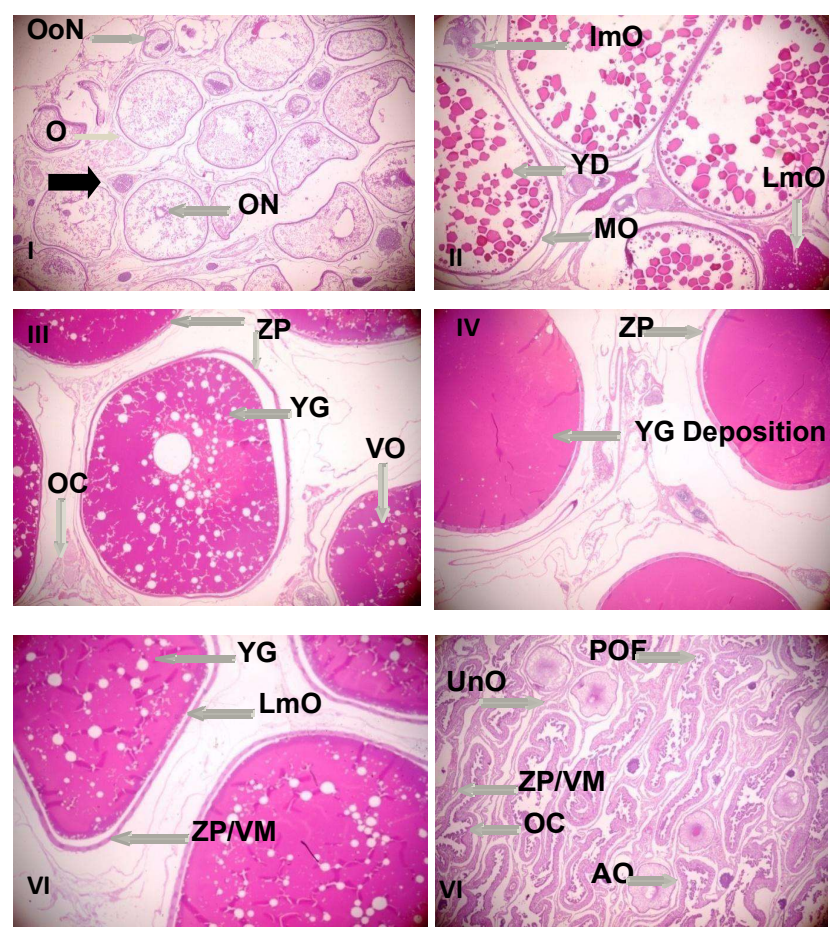

Fig. 3. Egg developmetal stages. I -VI: Ovaries of rainbow trout collected from three state owned farms in Kashmir from developmental period to degeneration period. I: Immature phase showing oogonial nests (OoN), oocyte nucleus (ON) with considerable oogoniums (0).II: Early Maturing phase captured immature oocytes (ImO) with scattered yolk droplets (YD) and consistent development of maturing oocytes (MO) and peripheral oocytes vesicle contained late maturing oocytes (LmO). III: Advance Maturing phase with considerable growth of vitellogenic oocytes (VO) along with appearance of zona pellucida (ZP) and showed yolk deposition by formation of globules (YG) with ooplasmic content (OC). IV: Mature/Spawning phase showed full yolk deposition with thinner zona pellucida (ZP). V: Late Maturing phase showed yolk globules (YG) and zona pellucida (ZP) of late maturing oocyte (LmO). VI: Spent phase, a snap shot of ruptured post ovulatory follicle (POF), unexpelled ova (UO), and ooplasmic content (OC) with irregular folds of zona pellucida (ZP)/vitelline memberane (VM) and atretic oocytes (AO) aboutr evealing atresia

\section{CONCLUSION}

Histological analysis of gonads revealed species has good intensity of oogenesis. The post ovulatory follicles were seen in late maturing phase. The atresia in trout fishes can be seen within spent phase as observed in this research. The length at first maturity recorded was at $28.7 \mathrm{~cm}$. The reproductive potential of these female trout generally increases with size but decrease in large, old fish.

\section{REFERENCES}

Alp A, Kara C and Buyukcapar HM 2003. Reproductive biology of 
brown trout, Salmo trutta macrostigma Dumeril 1858, in a tributary of the Ceyhan River which flows into the eastern Mediterranean sea. Journal of Applied Ichthyology 19: 346-351.

Arsalan M and Aras NM 2007. Structure and reproductive characteristics of two brown trout (Salmo trutta) populations in the Coruh River Basin, North-Eastern Anatolia, Turkey. Turkish Journal of Zoology 31: 185-192.

Dhara K, Saha S, Mukherjee D and Saha NC 2021. Comparative acute toxicity of mercury to air breathing fish, Channa gachua and non air breathing fish Cyprinus carpio (Linn.): Ethological and Heamatological Consideration. Indian Journal of Ecology 48(5): 1243-1253

Farmer BM, French DJ W, Potter IC, Hesp SA and Hall NG. 2005. Determination of biological parameters for managing the fisheries for Mulloway and Silver Trevally in Western Australia. Centre for Fish and Fisheries Research Murdoch University, Murdoch Western Australia 6150, Fisheries Research and Development Corporation Report FRDC Project 2002/004, 150 p.

Gadekar GP 2014. Studies on the Seasonal Histomorphological changes in the ovary of Indian major carp, Labeo rohita (Ham.). The Bioscan 9(3): 1037-1042.

Hussain S 2014. Studies on the growth and reproductive biology of Schizothorax niger in Dal lake, Kashmir. M.F.sc thesis submitted to faculty of fisheries, Rangil SKUAST-Kashmir.

Mahmoud HH 2009. Gonadal Maturation and Histological Observations of Epinephelus areolatus and Lethrinus nebulosus in Halaieb/Shalatien Area "Red Sea", Egypt. Global Veterinaria 3(5): 414-423.

Mishra P, Ray S, Al Khatib AMG, Abotaleb M, Tiwari S, Badr A and Balloo R 2021. Estimation of fish production in India using ARIMA, Holt's Linear, BATS and TBATS models. Indian Journal of Ecology 48(5): 1254-1261

Qadri S, Shah TH, Balkhi MH, Bhat BA, Bhat FA, Najar AM, Asmi OA, Farooq I and Aalia S 2019. Gonadal Maturation and Histological observations of $S$. curvifrons in river Jhelum Kashmir. Indian Journal of Animal Research 53(1): 71-76.

Rahemo ZIF and Al-Shatter Nabela MS 2012. Observation on reproductive organs and tissues of two freshwater cyprinid fishes. Journal of Medicine and Medical Sciences 3(12): 764773.

Scuba BR and Meheta SN 2012. Ovarian histomorphology and gonadial cycle of freshwater Garfish Xenentodon cancila (Hemilton- Buchanan) (Beloniformes:Belonidae). BIBECHANA 89 (96-104): 96.

Shah TH 2012. Biology and Stock Assessment of Oil Sardine Sardinella longiceps (Valenciences 1847) from Ratnagiri waters. Ph.D. Thesis submitted to Central Institute of Fisheries Education Mumbai. 170.

Shah TH, Balkhi MH and Asimi OA 2009. Experiments on the Rearing of Rainbow Trout Oncorhynchus mykiss Walbaum in Kashmir. Nature Environment and Pollution Technology 8(2): 225-230.

Shahi N, Pandey J, Mallik SK, Sarma D and Das P 2014. Gonadal development stages of wild male Golden Mahseer, Tor putitora from Nainital Region of Uttarakhand, India. Journal of Ecophysiology and Occupational Health 14(3 \& 4): 129-134.

Sharma RK and Bhat RA 2015. Seasonal testicular cyclicity in rainbow trout (Oncorhynchus mykiss). American-Eurasian Journal of Agriculture and Environmental Sciences 15(10): 2004-2010.

Shinkafi BA and Ipinjolu JK 2012. Gonadosomatic Index, Fecundity and Egg Size of Auchenoglanis occidentalis (Cuvier and Valenciennes) in River Rima, North-Western Nigeria. Nigerian Journal of Basic and Applied Science 20(3): 217-224.

Tharakan J 2014. A comparative study on length at first maturity of Puntius amphibius and Puntius parrah. Millennium Zoology 15(1): 22-24.

Verma R 2013). Maturation and Spawning Biology of a Hill Stream Major Carp Labeo dyocheilus (McClelland 1839) from Central Himalaya, India. International Journal of Advanced Fisheries and Aquatic Science 1(1): 39-48.

Virchow R 1858. Die Cellularpathologie in ihrer Begrundung auf Physiologische und Pathologische Gewebelchre. Berlin: August Hirschwald.

Wood H 1930. Scottish herring shoals pre-spawning and spawning movements. Fish. Board Scot. Sci. Invest 1: 1-71. 